\title{
Corporate Governance and Firm's Compliance on Disclosure of International Financial Reporting Standards-Indonesian Evidence
}

\author{
Krismiaji $^{1, *}$, Surifah ${ }^{2}$ \\ ${ }^{1}$ Department of Accounting, Accounting Academy of YKPN, Yogyakarta, Indonesia \\ ${ }^{2}$ Department of Economic and Business, Yogyakarta Technology University, Yogyakarta, Indonesia
}

Email address:

xmiaji@gmail.com (Krismiaji), surifah.ifah@gmail.com (Surifah)

${ }^{*}$ Corresponding author

\section{To cite this article:}

Krismiaji, Surifah. Corporate Governance and Firm's Compliance on Disclosure of International Financial Reporting Standards-Indonesian Evidence. International Journal of Accounting, Finance and Risk Management. Vol. 4, No. 1, 2019, pp. 24-33.

doi: 10.11648/j.ijafrm.20190401.13

Received: February 21, 2019; Accepted: April 4, 2019; Published: May 6, 2019

\begin{abstract}
This paper describes empirical research which investigateshow corporate governance (CG) affects the compliance level of disclosure for International Financial Reporting Standards (IFRS) in 2013 and 2014, the two yearsafter full IFRS adoption. The CGis proxy by the board's structure, characteristics of an audit committee, and shares ownership structure, whereas IFRS disclosure's level of compliance is measured by disclosure index. This research uses ordinary least square to investigate the effect of corporate governance on the level of IFRS disclosurecompliance along with profitability, industry, and leverage as control variables. This research finds that five elements of CG characteristics which are board's independence, board's size, audit committee'sindependence, audit committee's size, and management's ownershippositively affect the level of IFRS disclosurecompliance. Yet, the block holder's ownership negatively affects the compliance level of IFRS disclosure, whereas government ownershipdoes not affect the compliance level of IFRS disclosure. This study provides additional evidence about the association of CG and the level of IFRS disclosure compliance by using Indonesian data. Furthermore, involvingfive elements of corporate governance mechanisms, this study provide additional finding about corporate governance comprehensively. Finally, this research provides values for all users of information including standard setters and other regulators to enhance reporting quality standards in Indonesia.
\end{abstract}

Keywords: CG Characteristics, IFRS Disclosure, Level of Compliance

\section{Introduction}

The objective of this study is to find empirical evidence about the compliance level of Indonesian public firms toward IFRS mandatory disclosures in the corporate governance perspectives. This research is motivated by previous research investigated the effect of IFRS on accounting information quality which reports mixed results. Some report that IFRS increases accounting information quality $[23,60,61,20,39$, $31,11,19,21,42]$, some report that IFRS decreases accounting information quality [51-52], and some report that IFRS does not affect accounting information quality [34, 12, 33]. Therefore, we conduct further research to investigate the compliance level of Indonesian firms toward mandatory disclosure post full mandatory IFRS implementation.

Following several accounting scandals involving huge companies, i.e. WorldCom, Enron, and Xerox, accounting information quality had been the tireless concern, especially among practitioners, standard and regulation setters, government, and other stakeholders [38]. Research performed by Byrne and Deakin et al. reports that the scandal of financial accountingis one of the triggers for corporate governance (CG)sincecompany's problems are usually related to the weaknesses of corporate governance systems $[15,22]$. Such corporate problems are the effect of the conflictof interest between the agent (management) and owners (shareholders).

Corporate accounting information quality is affected by the 
accounting standard and motivation preparers of financial statements to conform to the accounting standards [41]. In the last decades, many countries had implemented IFRS. This makes IFRS become one of the dominant change in the accounting regulatory. Yet, the IFRS implementation itself does not guarantee that a firm is able to produce high-quality accounting information. Firms need to act in accordance with all reporting and disclosure standards. Many research about IFRS compliance have been performed, for example, Hodgdonet al. which investigate the effect of IFRS's compliance find that the level of IFRS compliance negatively correlated withearnings forecast errors [29]; whereasBova and Pereirareport that the compliance of IFRS's disclosure positively affects themagnitude of share return [13]. Both types of research show that the IFRS implementation does not have an impact on the improvement of information quality if it is not followed by full compliance with accounting standard.

Other research performed byPope and Measly; Cuijpers; and Krismiaji et al. who find evidence that firm-level corporate governance mechanism has an important effect on the financial report preparer to obey IFRS, especially in the lower enforcement country such as Indonesia [53, 41]. Another research performed by Brown finds the benefit IFRS attainment is affected by several aspects, such as regulation, reporting standards, and compliance level [14]. Moreover, reporting quality and benefit of IFRS adoption also depend on the incentive power of financial statement preparers to comply and disclose high-quality information [38]. This incentive depends on the degree of enforcement.

Basically, disclosures reflect the effectiveness of CG since CG provides information transparency both for shareholders and other stakeholders [38]. Additionally, a high-quality disclosure will happen if a corporation has a strong CG [63]. Disclosure level usually increases when corporations implement IFRS. Moreover, the higher the quality of CG a company has, the broader the financial information is disclosed. This view is in line with Forker who argues that governance mechanisms like the independence of board increase monitoring of firms' disclosure quality [25] and Williamson who suggests that board independence leads to higher transparency [66].

In term of governance, audit committee, as one of governance elements, is assumed as an important instrument to increase the trustworthiness and precision of financial information [62]. An audit committee in the firms increases information quality, quality of disclosure, the effectiveness of the internal control system, and the financial statements quality [25, 28]. The structure of ownership is another governance mechanism which also important. This is supported by Makhija and Patton who argue that disclosure degree and disclosure qualitiesare a resultof the conflict of interest between the agent (management) and principle (shareholders) [43]. Since majority shareholders have more power than the minority one, they are likely to manage the level of information disclosure to maximize their own interest.
Governance mechanism is formed to ensure that managers work primarily to produce advantages for shareholders by enhancing a firm's economic value. Regulatory authorities, in order tokeepthe interests of shareholders, have issuedsome corporate governance regulations [16]. In Indonesia, such CG regulations are Minister Regulation No.01/MBU/2011 about good corporate governance and The Indonesia Corporate Governance Manualwhich is released by Financial Service Authority in the year of 2014.

Recently, there is increasing awareness about the benefit of $\mathrm{CG}$ to improve the quality of financial information. Yet, the involvement of corporate governance in the firm's research is still limited, if any, especially in an emerging market like Indonesia. Therefore, this research aims to fill such literature gap about the effect of corporate governance on the compliance of IFRS disclosure. This research also complements previous research and literature on corporate governance. Previous research investigated the effect of governance characteristics and IFRS compliance level in emerging countries had performed by Al-Akra et al. and Juhmani $[6,38]$. Nevertheless, there are still limited similar research which investigates three categories of governance mechanism in a study, which are characteristics of the boards, characteristics of the audit committee, and structure of the ownership. This opens an opportunity to do research which investigates how corporate governance affectsthe level of IFRS disclosure requirement. Therefore, this research aims to investigate the impact of three categories of governance mechanism i.e. characteristics of boards, characteristics of audit committee, and structure of ownership on the compliance to IFRS mandatory disclosures. Specifically, the objective of this paper is to offer an answer to the following research questions:

RQ1: Do boards characteristics, which consist of boards independence and boards size affectsthe compliance to IFRS mandatory disclosure?

$R Q 2$ : Do audit committee characteristics, which consist of audit committee independence and audit committee size affectsthe compliance toIFRS mandatory disclosures?

RQ2: Do ownership structures, which consist of the ownership of block holders, managerial, and government affects the compliance to IFRS mandatory disclosure?

This paper is structured as follows: Section 2 describes the literature review andhypotheses development. Section 3 describes the research method. Section 4 presents the result analysis discussion. Finally, Section 5 presents conclusions, implications, limitations, and the opportunity for further research.

\section{Literature Review and Hypothesis Development}

Corporate governance mechanism affects the compliance to IFRS mandatory disclosure. The important role of external and independent boards of the director in the process of governancelead to the recommendation for the presence of 
independent members on the boards of director [38]. The quality improvement of financial reporting practice was recognized as one of the main benefits for corporations from having an audit committee [54]. Additionally, corporate governance reform in many countries had strengthened committee roles in the supervision of the financial reporting process [58].

One of the important jobs for an audit committee is to recognize the interdependence between the audit committee, management, and external auditors [55]. An audit committee will be reliable if it has members with sufficient competence and full independence. Hannifa and Cooke stated that ownership structure establishes the extent of the monitoring which in turn affects the disclosure level [27]. Therefore, in a non-concentrated owned company, the managers may disclose the extra information to show that theyhad worked for the shareholder's optimum interest. In contrast, in a more concentrated owned company, managers may disclose less information. Previous research investigated the relationship between governance mechanism and financial information disclosure. Samaha et al. find that the level of disclosure is lower in the highly concentrated owned companies [56]. The level of disclosure increased in companies which have independent directors.

Verriest et al. investigate the relationship between corporate governance and the choice to adopt IFRS for European public companies in the year of 2005 [63]. Theyfind that companies with strong CG are likely to present extra information. Additionally, Omar finds that some new regulations positively affect the level of disclosure [49]. The lower of compliance lead to disclosure practice became a problem, especially when management has the incentive to evade their compliances [10] and when the enforcement of the rules and corporate governance are not strong enough [47].

\subsection{Board Independence and IFRS Disclosure Compliance}

Board independence is presumedas one of the company's governance characteristics. Agency theory argues that the duality role reduces boards' monitoring ability. This lead to increases in agency problem which in turns affect boards independence [27]. Yermack and Ho et al. find that when boards and CEO are performed by the same person, there is a new agency problem because a person has both capability and power to reduce the flow of information to external parties [67, 27].

Chen and Jaggi support the presence of independent boards by arguing that the independent boards may provide a recommendation to management about a strategic decision, i.e. the decision to disclose information [17]. Moreover, the more independent board's member, the better performance in controlling and monitoring for decisions of management. This is supported by Abdullahwho finds that independence of board positively affects the quality of earnings [2] and Abdullah and Nasir who show that the independence of board is not associated withearnings management [3]. Finally, Juhmani find that the board's independence positively affects the level of the IFRS disclosures [38]. Based on the above description, we stated thehypotheses as follows:

$\mathrm{H}_{1}$ Board independence positively affectsthe level of IFRS disclosure compliance.

\subsection{Board Size and IFRS Disclosure Compliance}

Previous research about the association between board size and disclosure are mixed. The large board is believed to be more effective to monitor the financial reporting process because firms have more resources to assign board members who have relevant knowledge and skill [59]. Yet, this does not guarantee that a large board affects positively on the management attitude to comply with the disclosure requirement. Although board size leads to the increase of monitoring ability for the board, John and Senbet argue that the benefit of better monitoring should be expensed by the incremental cost in which there is a decrease in effective communication and ability of decision-making as there are more people in the same room [37]. From the standpoint of the small board's effectiveness, Yermack finds that board size negatively affects firm value. This is evidence of the negative effect of large boards [67]. Differently, Alfraih findsa positiveassociation between the size of boards and the level of IFRS disclosure compliance [8]. Additionally, Al-Akra et al. find that board size affects positively the IFRS disclosure compliance level [6]. The last research conducted by Juhmani finds that there is no association between board size and IFRS compliance level [38]. Based on the above description, we stated thehypotheses as follows:

$\mathrm{H}_{2}$ Board'ssizepositively affects the level of IFRS disclosure compliance.

\subsection{Audit Committee Independenceand IFRS Disclosure Compliance}

Audit committee independence plays an important role in the financial reporting process, especially in term of mandatory disclosure compliance. This is supported by Klein who argues that the independence of audit committee affects the director's capability to effectively control the financialaccounting reports [40]. Additionally, the independence of audit committee had been argued as an obligatory requisite for an audit committeein order toaccomplish its responsibility objectively [24, 1]. Previous research performed by Sellami and Fendri find a positive association between the independence of audit's committee and the level of IFRS disclosure compliance [57], whereas Al-Akra, Eddie, and Ali find that audit committee's independence positively affects IFRS disclosure compliance level [6]. The finding of Al-Akra et al. was confirmed by Juhmani who finds that the audit committee's independence positively affects IFRS disclosure compliance level [38]. Based on the above description, we stated thehypotheses as follows:

$\mathrm{H}_{3}$ Audit committee's independence positively affectsthe level of IFRS disclosure compliance. 


\subsection{Audit Committee Sizeand IFRS Disclosure Compliance}

Generally, the size of an audit committeeleads to improvement incorporate governance. This is supported by Vicknair et al. who stated that the audit committee should have sufficient members to perform it's responsibilities effectively [64]. Previous research performed by Maznifinds that the audit committee size is associated with the level of compliance with IFRS disclosure requirements [45]. Additionally, Anderson, Mansi, and Reeb report that the bigger theaudit committee size, the more effective the audit committee function, because audit committee has more resources and competence to handle any duties and problems in the process of financial reporting [9]. Moreover, they find that the size of audit committee positively affects company disclosure's transparency [9]. Finally, Al-Akra, Eddie, and Ali and Alanezi and Albuloushi find that audit committee sizepositivelyaffect the level of IFRS disclosure compliance $[6,7]$. Based on the description, we stated the hypotheses as follows:

$\mathrm{H}_{4}$ Audit committeesizepositively affectsthe level of IFRS disclosure compliance.

\subsection{Blockholder's Ownership and IFRS Disclosure Compliance}

When a company's shares are owned by large block holders, a firm is controlled by the small number of shareholders; consequently, the share's ownership is concentrated. Noe argue that concentrated ownership structure could be functioned as a monitoring mechanism which effectively prevents managers to expropriate the firm's resources for their benefits [48]. On the basis of the efficientmonitoring hypotheses, the largeblock holders are supposed to motivate firm's manager to provide extra information in order to enhance theprice of firm's share and the value of the firm. Investors who have a large portion of the company's share may obtain the company's information from internal sources. Therefore, Marston and Polei argue that the larger the firm's share owned by the smaller people, the less information is disclosed by the company, because the dominant investors can access information internally [44]. This is supported byAbdullahwho documentsthat outsideblock holders negatively affects the status of financial distress [2]. Therefore, the hypothesis can be formulated as follow:

$\mathrm{H}_{5}$ Blockholders' ownershipnegatively affectsthe level of IFRS disclosure compliance.

\subsection{Managerial Ownership and IFRS Disclosure Compliance}

Managers who have the company's shares usually are motivated to increase a firm's value, enhance shareholders' wealth, and improve their own wealth [38]. Therefore, information disclosure will improve when managers have a large firm's share. This happens because they may obtain benefit from the more disclosure in the form of share price increase. Consequently, managers are expected to have a similar interest as other shareholders. They will also more conform to the standard of financial information reporting and present more mandatory information. Based on the description, we stated hypotheses as follows:

$\mathrm{H}_{6}$ Managerial ownershippositively affectsthe level of IFRS disclosure compliance

\subsection{Government Ownership and IFRS Disclosure Compliance}

Government ownership could have a positive or negative impact on information quality as well as disclosure compliance. Previous research performed by Ghazali and Weetman find no association between the ownership of government and the level of disclosure and the extent of transparency [26]. They argue that in emerging countries, the state-owned companies tend to have strong political connections and consequently state-owned companies are likely to produce and presentthe less information in order to protect the political network and even their beneficial shareholders. Juhmani find thatgovernment ownership does not associate with IFRS disclosure compliance[38]. Based on the above description, we statedhypotheses as follows:

$\mathrm{H}_{7}$ Government ownershipnegatively affectsthe level of IFRS disclosure compliance.

\section{Research Method}

\subsection{Sample Selection}

After gradually adopting IFRS since 2008, Indonesian companies fully adopt IFRS in the year of 2012. Consequently, Indonesian companies are required to prepare a financial statement based on IFRS start on the fiscal year of 2012. Therefore, the year selected for this research is 2013 to 2014, two years after full IFRS adoption. This research uses a purposive sampling method to select the firm's sample. To be involved in the sample, a company should be listed on the Indonesian Stock Exchange in the year 2012then after. Secondly, the firms shouldhave adopted IFRSsince 2012. Thethird requirement is that the firms should have publicly available data. The data derives from the Indonesian CapitalMarket Directory (ICMD), www.idx.co.id, and the firm's website. Data is analyzed using multiple linear regression. Similar to the previous research, we use OLS (ordinary least-squares) to testour hypotheses. To achieve ourresearch objective, all IFRS which are mandatorily implemented since 2012 were included. The reason is that our research objective is to test the entity's level of compliance in the first-time IFRS adoption.

\subsection{Variables' Definition and Measurement}

Dependent variable used in this research is the disclosure compliance index (DIND). Previous research investigated disclosure had constructed various disclosure compliance indices. Some research uses a self-constructed index and some researchers use the developed index which is designed by others. As it is used by Hodgdon et al. this research also 
employs an index, which is constructed based on Indonesian regulations and consists of elements which mandatorily should be disclosed [30]. Disclosure compliance is measured by a dummy approach and compliance score is calculated for each company. Compliance score total for a company is total disclosure items presented in the financial statements. If an item is not stated in the financial statements, it isdelighted as not applicable. The next, disclosure index is calculated to proxy the compliance level of IFRS disclosure. Disclosure index is the ratio between the actual score for a company divided by the possible maximum score.

This studyuses seven independent variables which are board independence (BIND), board size (BSIZE), audit committee independence (ACIND), the audit committee size (ACSIZE), block holder's ownership (BLOK), managerial ownership (MAN), and government ownership (GOV). BSIZE is measured by the total of the board's member, ACIND is measured by the proportion of non-executive members, ACSIZEis measured by the total of audit committee members, BLOK is measured by the ownership percentage with a minimum of $5 \%$ ownership, MAN is measuredand calculated by the proportion of shares owned by managers, and GOV is measured by a dummy variable which has a value of 1 if a companyis related to the government and 0 otherwise.

This research uses three control variables, namely profitability (PROF) which is measured by return on equity (ROE), industry (IND), measured by dummy variable which has value of1 for financial company and 0 otherwise, and financial leverage (LEV) which is ratio between firm's total liabilities and firm's total assets. We use profitability as one of the control variables because profitable companies are likely to report more information [38]. Companies in a certain industry may face specific circumstances which affect their information reporting practices. Wallace et al. argue that industries aredissimilar to each other in term of operation and financial reporting practices [65]. Moreover, firms in the highly regulated industry, such as banks and insurance, may become a subject of oversight by a government which in turn affects significantly their policy and practice of information disclosure [50]. Therefore, some of the previous research about disclosure excludes financial industry from the samples and some use all industries, including this research. The empirical result on the correlation between information disclosures and industry's type tend to be inconclusive. Cooke, Meek et al., and Samaha et al. find that there is an association between the two variables $[18,46,56]$, whereas Inchausti and Owusu-Ansah find that there is no association between them $[32,50]$. Agency theory stated that information disclosure level increase when the firm's financial leverage increase [38]. In countries where companies highly depend on financial institution as a source of funding, companies are expected, especially for large debt companies, todisclose more information [5]. Such companies are likely to present more detail information in order to get additional fund from financial institutions.

\subsection{Research Model Specification}

The statistical method to test the hypotheses is multiple regressions using anordinary least squares (OLS)model. To predict the effect of all independent variables which areBIND, BSIZE, ACIND, ACSIZE, BLOK, MAN, and GOVon dependent variable which is disclosure index (DIND), the research uses models as follows:

(1) DIND $=\alpha+\beta_{1}$ BIND $+\beta_{2}$ BSIZE $+\beta_{3}$ ACIND + $\mathrm{B}_{4} \mathrm{ACSIZE}+\beta_{5} \mathrm{BLOK}+\beta_{6} \mathrm{MAN}+\mathrm{B}_{7} \mathrm{GOV}+\beta_{8} \mathrm{PROF}$ $+\beta_{9}$ IND $+\beta_{10}$ LEV $+\varepsilon$

DIND is disclosure index, BIND is the boards independence, BSIZE is board's size, ACIND is audit committee's independence, ACSIZE is audit committee's size, BLOK is block holders' ownership, MAN is managerial ownership, GOV is Government's ownership, PROF is profitability, IND is the industry type, LEVis a financial leverage, and e is error term (residual). We also split the first model, Model (1), intothree additional models which are Model (2), Model (3), and Model (4) to determine the effect of each category of board characteristics on the disclosure index as follows:

(2) DIND $=\alpha+\beta_{1}$ BIND $+\beta_{2}$ BSIZE $+\beta_{3}$ PROF $+\beta_{4}$ IND + $\beta_{5} \mathrm{LEV}+\varepsilon$

(3) $\mathrm{DIND}=\alpha+\beta_{1} \mathrm{ACIND}+\beta_{2} \mathrm{ACSIZE}+\mathrm{B}_{3} \mathrm{PROF}+\beta_{4} \mathrm{IND}$ $+\beta_{5} \mathrm{LEV}+\varepsilon$

(4) DIND $=\alpha+\beta_{1} \mathrm{BLOK}+\beta_{2} \mathrm{MAN}+\beta_{3} \mathrm{GOV}+\beta_{4} \mathrm{PROF}+$ $\beta_{5} \mathrm{IND}+\beta_{6} \mathrm{LEV}+\varepsilon$

\section{Data Analysis and Result Discussion}

On the basis of the described sampling process, this research uses491 firm sample. The sample data are detailed in the industry sector and presented in Table 1 . We include all industrysectors which have available and complete data.

Table 1. Firm Sample Data.

\begin{tabular}{lll}
\hline No & Industry Sector Type & Number \\
\hline 1 & Agriculture & 20 \\
2 & Basic industry and chemicals & 39 \\
3 & Consumer goods industry & 63 \\
4 & Infrastructure, utilities, and transportation & 40 \\
5 & Mining & 37 \\
6 & Miscellaneous industry & 55 \\
7 & The property, real estate, and building constructions & 50 \\
8 & Finance & 79 \\
9 & Trades, services \&investment & 108 \\
& Total & 491 \\
\hline
\end{tabular}

\subsection{Univariate Analysis}

Table 2 presents descriptive statistics for the sample data. This table shows thatDINDhasa mean value of0.716and standard deviation of0.080. Because DIND is a measure ofdisclosure compliance, therefore the higherofvalue DIND the more the firm'scompliance. BIND and BSIZE has a mean value of 0.386 and 4.109 with a standard deviation of 0.170 and 1.970 respectively. ACIND and ACSIZE have a mean value of 0.133 and 2.870 with a standard deviation of 0.182 
and 1.057 respectively, whereas BLOK, MAN, and GOV

deviation of $3.658,0.088$ and 0.213 respectively.

have a mean value of $0.878,0.024$ and 0.047 with a standard

Table 2. Descriptive Statistics.

\begin{tabular}{llllll}
\hline & Mean & Median & Maximum & Minimum & Std. Dev \\
\hline DIND & 0.716 & 0.730 & 0.990 & 0.390 & 0.080 \\
BIND & 0.386 & 0.333 & 1.500 & 0.000 & 0.170 \\
BSIZE & 4.109 & 3.000 & 22.000 & 0.000 & 1.907 \\
ACIND & 0.133 & 0.000 & 0.750 & 0.000 & 0.182 \\
ACSIZE & 2.870 & 3.000 & 8.000 & 0.000 & 1.057 \\
BLOK & 0.878 & 0.698 & 70.880 & 0.000 & 3.658 \\
MAN & 0.024 & 0.000 & 0.742 & 0.000 & 0.088 \\
GOV & 0.047 & 0.000 & 1.000 & 0.000 & 0.213 \\
PROF & 12.526 & 10.070 & 423.210 & -233.710 & 44.172 \\
IND & 0.159 & 0.000 & 1.000 & 0.000 & 0.366 \\
LEV & 0.581 & 0.530 & 12.000 & 0.000 & 0.681 \\
\hline
\end{tabular}

\subsection{Bivariate Analysis}

To test research hypotheses, we use ordinary least square (OLS) regression. All classical assumptions test for these techniques have been done. The result proves that the residual data is normally distributed, no multicollinearity and no heteroscedasticity in the data. Specifically, Table 3 presentsthe multicollinearity test result and proves that the correlation between the independent variable is small with the highest value of 0.306 which correlate ACSIZE and BSIZE. This means that there is nomulticollinearity. Table 3also shows that, except for GOV, all independent variables correlate in a similar direction as stated in each hypothesis. Although only one variable which has a significant correlation, namely ACSIZE, these are the initial indication for proving the hypotheses. Therefore, this result will be furthertested in the multivariate analysis.

Table 3. Bivariate Analysis.

\begin{tabular}{|c|c|c|c|c|c|c|c|c|c|c|}
\hline & DIND & BIND & BSIZE & ACIND & ACSIZE & BLOK & MAN & GOV & PROF & IND \\
\hline BIND & .081 & & & & & & & & & \\
\hline BSIZE & .087 & .045 & & & & & & & & \\
\hline ACIND & .054 & $.237^{* *}$ & .060 & & & & & & & \\
\hline ACSIZE & $.099^{*}$ & $.196^{* *}$ & $.306^{* *}$ & $.128^{* *}$ & & & & & & \\
\hline BLOK & -.062 & -.031 & .006 & -.002 & -.002 & & & & & \\
\hline MAN & .057 & .019 & .049 & .056 & -.013 & .021 & & & & \\
\hline GOV & .003 & -.065 & $.146^{* *}$ & -.045 & $.209^{* *}$ & -.042 & -.058 & & & \\
\hline IND & .009 & $.248^{* *}$ & -.065 & $.148^{* *}$ & $.210^{* *}$ & .076 & .016 & .038 & -.006 & \\
\hline Lev & -.012 & .081 & -.041 & .000 & -.046 & -.018 & -.014 & .012 & -.013 & .057 \\
\hline
\end{tabular}

Notes: ** and * means that correlation is significant at the 0.01 and 0.05 levels, respectively (2-tailed).

\subsection{Multivariate Analysis}

Table 4 presents the result of multiple regression analysis. The result explains that the value of adjusted $R^{2}$ and $F$ indicate all models are significant. Yet, there are distinctions in the explanatory power as is shownby the value of adjusted $\mathrm{R}^{2}$. The value adjusted $\mathrm{R}^{2}$ is 31.6 percent; 1.4 percent; 35.9 percent, and 42.7 percent for Model 1, 2, 3, and 4 respectively. To test whether board independence affects the level of IFRS compliance (H1), the variable to be investigatedisboard independence (BIND). Table 4 presentsa positive $(0.672)$ and significant coefficient ofBINDin the level of $1 \%$. This result shows that board independence positively affects the firm's IFRS compliance. Therefore we conclude that hypotheses 1 which states that board independence positively affectsthe level of IFRS disclosure compliance is confirmed and supported by the research data. Thus, the more independent the board, the more comply a firm toward IFRS. To test whether board sizepositively affects the level of IFRS compliance $(\mathrm{H} 2)$, the variable to beinvestigatedisboard size (BSIZE). Table 4 presents a positive $(0.004)$ and significant coefficient of BSIZE at the level of $1 \%$. This result shows that board size positively affects the firm's IFRS compliance. Thus, we conclude that hypotheses 2 which states that board size positively affects thelevel of IFRS disclosure compliance is supported by research data. Aninference of the result is that the bigger the board size, the higher the IFRS compliance of the firm. The regression results in Model 1 to test $\mathrm{H} 1$ and $\mathrm{H} 2$ is supported by and consistent with the result from Model 2 which presents a positive coefficient of BIND (0.043) and BSIZE (0.004) and significant at the level of $\alpha=0.01(p=0.000)$. This result in line with Jensen who stated thatboard independence is necessary to givepressure on managementto disclose more information, which meets the shareholders' interest [36]. Therefore, the existence of an independent board is important for the effectiveness of the boards. This is believed to enhancethe compliance of the disclosurerequirements of the firm. This will increase the quantity and quality of information disclosed. Moreover, this finding supports prior 
studies performed by Abdullah who findsthat board independence affects positively the firm's earnings quality [4], Abdullah and Nasirwho report thatboardindependence is not associatedwith the accrual management [3], Chen, and Jaggiwho find that board independence positively affects the extent of information disclosure [17], and Juhmani who finds that board independence positively affectsthe firm's compliance level of IFRS disclosure [38]. These findingsare also in line with the statement that the larger boards lead to the higher monitoring effectiveness offinancial reporting. A rational explanation of this is that a company, with the larger board members, has more choicesto hire directors and the member of the audit committee who has thesufficient and relevant expertise, knowledge and skill [59].

(1) DIND $=\alpha+\beta_{1}$ BIND $+\beta_{2}$ BSIZE $+\beta_{3}$ ACIND + $\mathrm{B}_{4} \mathrm{ACSIZE}+\beta_{5} \mathrm{BLOK}+\beta_{6} \mathrm{MAN}+\mathrm{B}_{7} \mathrm{GOV}+\beta_{8} \mathrm{PROF}$ $+\beta_{9}$ IND $+\beta_{10}$ LEV $+\varepsilon$

(2) DIND $=\alpha+\beta_{1}$ BIND $+\beta_{2}$ BSIZE $+\beta_{3}$ PROF $+\beta_{7}$ IND + $\beta_{8} \mathrm{LEV}+\varepsilon$

(3) $\mathrm{DIND}=\alpha+\beta_{1} \mathrm{ACIND}+\beta_{2} \mathrm{ACSIZE}+\mathrm{B}_{3} \mathrm{PROF}+\beta_{4} \mathrm{IND}$ $+\beta_{5} \mathrm{LEV}+\varepsilon$

(4) $\mathrm{DIND}=\alpha+\beta_{1} \mathrm{BLOK}+\beta_{2} \mathrm{MAN}+\beta_{3} \mathrm{GOV}+\beta_{4} \mathrm{PROF}+$ $\beta_{5} \mathrm{IND}+\beta_{6} \mathrm{LEV}+\varepsilon$

Table 4. Regression Analysis.

\begin{tabular}{|c|c|c|c|c|c|c|c|c|}
\hline Variable & $\begin{array}{l}\text { Model 1Coefficient } \\
\text { (t-Statistic) }\end{array}$ & & $\begin{array}{l}\text { Model 2Coefficient (t- } \\
\text { Statistic) }\end{array}$ & & $\begin{array}{l}\text { Model 3Coefficient } \\
\text { (t-Statistic) }\end{array}$ & & $\begin{array}{l}\text { Model 4Coefficient (t- } \\
\text { Statistic) }\end{array}$ & \\
\hline Intercept & $0.672(409.557)$ & $* * *$ & $0.681(80.349)$ & $* * *$ & $0.694(546.788)$ & $* * *$ & $0.716(958.617)$ & $* * *$ \\
\hline BIND & $0.041(18.600)$ & $* * *$ & $0.043(2.791)$ & $* * *$ & & & & \\
\hline BSIZE & $0.004(26.849)$ & $* * *$ & $0.004(3.193)$ & $* * *$ & & & & \\
\hline ACIND & $0.005(3.888)$ & $* * *$ & & & $0.012(10.691)$ & $* * *$ & & \\
\hline ACSIZE & $0.004(12.752)$ & $* * *$ & & & $0.006(18.588)$ & $* * *$ & & \\
\hline BLOK & $-0.001(-2.406)$ & $* *$ & & & & & $0.001(-3.499)$ & $* * *$ \\
\hline GOV & $-0.007(-0.115)$ & & & & & & $0.016(4.525)$ & $* * *$ \\
\hline PROF & $0.012(1.056)$ & & $0.004(0.777)$ & & $0.003(4.652)$ & $* * *$ & $0.005(5.228)$ & $* * *$ \\
\hline IND & $-0.002(-3.012)$ & $* * *$ & $-0.002(-0.308)$ & & $-0.004(-7.384)$ & $* * *$ & $0.005(3.791)$ & $* * *$ \\
\hline LEV & $0.001(0.639)$ & & $-0.006(-0.016)$ & & $0.001(4.067)$ & $* * *$ & $0.001(0.987)$ & \\
\hline Adj. $R^{2}$ & 0.316 & & 0.014 & & 0.359 & & 0.427 & \\
\hline F-statistic & 430.835 & $* * *$ & 3.940 & $* * *$ & 109.895 & $* * *$ & 122.923 & $* * *$ \\
\hline
\end{tabular}

$* * *, * *, *$ show that coeficient is significant at $0.01,0.05$, and 0.1 respectively.

To test whether audit committee independence affects positivelythe level of IFRS compliance (H3), the variable to be investigatedis ACIND. Table 4 presents a positive $(0.005)$ and significant coefficient ofACIND at the level of $1 \%$. This result shows that the audit committee independence positivelyaffects IFRS compliance. Therefore, we conclude that $\mathrm{H} 3$, which states that audit committee independence positively affects the level of IFRS compliance, is supported by research data. The consequence of this evidence is that the more independent the audit committee, the higher the firm's IFRS compliance. To test the effect ofthe audit committeesizeon the level of IFRS compliance (H4), the variable to be investigatedis ACSIZE. Table 4 presents a positive $(0.004)$ and significant coefficient ofACSIZE at the level of $1 \%$. The result shows that the audit committee size positively affects IFRS compliance. We conclude that $\mathrm{H} 4$ which states that audit committeesize positively affectsthe level of IFRS compliance is supported by research data. An explanation of this evidence is that the bigger the audit committee size, the more comply the firm toward IFRS disclosure. The regression result in Model 1 to test $\mathrm{H} 3$ and H4 is supported by and consistent with the result from Model 3 regression which presents a positive and significant at the level of $\alpha=0.01(\mathrm{p}=0.000)$ coefficient of ACIND equals (0.012) and ACSIZE equals (0.006). This result supports some previous research performed by Al-Akra et al. and Juhmani who findthat the presence of an audit committee affects positively firm'scompliance of IFRS disclosure [6,
38]. Additionally, this evidence is also in line with the study which is performed byAlanezi et al. who find that the audit committee's size affects the level of IFRS disclosure compliance [7].

To test whether block holders' ownershipnegatively affects the level of IFRS compliance (H5), variable investigatedis BLOK. Table 4 presents a negative $(-0.001)$ and significant coefficient ofBLOKat the level of $5 \%$. This evidenceimplies that the block holders' ownershipaffects negatively the IFRS compliance's level. Therefore, we concludethat H5which states that block holders' ownershipnegatively affectsthe level of IFRS compliance is confirmed by researchdata. A consequence of this evidence is that the bigger block holders' ownership, the higher the extent offirm's IFRS compliance. To test whether managerial ownershippositively affects the level of IFRS compliance (H6), variable investigatedis MAN. Table 4 presents a positive $(0.036)$ and significant coefficient ofMANat the level of $1 \%$. This evidence shows that managerial ownershipaffects positively thefirm'sIFRS disclosure compliance's level. Thus we conclude that H6 which states that managerial ownershippositively affectsthe level of IFRS disclosure compliance is confirmed and supported by research data. This evidenceimplies that the bigger managerial ownership, the higher the extent of firm's IFRS compliance. Finally, to test whethergovernment' ownershipnegatively affects thelevel of IFRS disclosure compliance(H7), variable investigatedis GOV. Table 4 presents a negative $(-0.007)$ and an insignificant coefficient 
for GOV. This result shows that the government's ownershipdoes notaffectthe level of IFRS disclosure compliance. Therefore, it is concluded that $\mathrm{H} 7$ which states that government ownershipnegatively affectsthe level of IFRS disclosure compliance is not confirmed by research data. Thisevidenceimplies that the change in the government's ownership will not change the IFRS compliance of the firm.

The regression result in Model 1 to test H5 and H6 is supported and consistent with the result from Model 4 regression which presents a negative $(-0.001)$ and significant coefficient of BLOK at the level of $1 \%$ and a positive $(0.025)$ and significant coefficient of MAN at the level of $1 \%$. This finding supports previous research performed by Abdullah who finds that outsideblock holders negatively affects the status of financial distress [4]. For H7, the result of Model 1 is not supported by that of Model 4, since model 1 reports no significant value for GOV whereas model 4 report a positive sign at the level of $\alpha=0.01(p=0.000)$ coefficient of GOV (0.016). This finding may verify the importance of theGC to imposegovernment-owned companies to fully conformto therequirements of IFRS disclosure. This result is also in line with the view that CGmechanisms are supposed to affect management to more complywith IFRS disclosure. This finding confirms the previous study performed by Juhmani who reports that government ownership does not associate with the level of IFRS disclosure compliance [38].

\section{Conclusion}

This paper investigates the effect of corporate governancecharacteristics on the compliance level of IFRS disclosure. The research' evidenceshows that five of CG mechanisms - board's independence, board's size, audit committee'sindependence, audit committee's size, and management ownership -positively affectcompliance level of IFRS disclosure. Moreover, the resultsshow that the block holder's ownership negatively affects the compliance level of IFRS disclosure, whereas government ownershipdoes not affect the level of IFRS disclosure. The result supports $\mathrm{H} 1$ and $\mathrm{H} 2$ which stated that board characteristics positively affects the compliance level of IFRS disclosure. This result also supports $\mathrm{H} 3$ and $\mathrm{H} 4$ which stated that audit committee characteristics positively affects the compliance level of IFRS disclosure.

For ownership, the result provides mixed evidence. H5 which states that block holders ownership negatively affectscompliance level of IFRS disclosure and H6 which states that managerial ownership positively affectscompliance level of IFRS disclosure is supported by research data, whereas $\mathrm{H} 7$ which states that government ownership positively affects the level of IFRS disclosure compliance is not supported.

Some limitation exists in this research. First, this research uses data from one country which is Indonesia, which limits the generalization of the result. Future research is open to involving data for more countries. Second, this research uses data one year after full IFRS adoption. To enrich such disclosure literature, future research needs to consider data before full IFRS adoption in order to get a comparative picture of disclosure compliance.

\section{References}

[1] Abbott, L. J., Parker, S. and Peters, G. F. 2004. Audit committee characteristics and restatements, Auditing: A Journal of Practice and Theory, 23(1): 69-87.

[2] Abdullah, S. N. 1999. The role of corporate governance and ownership structure on accountingearnings quality, unpublished Ph.D. thesis, Universiti Utara Malaysia, Sintok.

[3] Abdullah, S. N. and Mohd Nasir, N. 2004. Accrual management and the roles of boards of directorsand audit committees among Malaysian listed companies: evidence during the Asian financialcrisis. IIUM Journal of Management \& Economics, 12 (1): 33-45.

[4] Abdullah, S. N. 2004. Board structure and ownership in Malaysia: the case of listed distressedcompanies, working paper, Universiti Utara Malaysia, Sintok.

[5] Ahmaed, K. and Nicholls, D. 1994. The impact of nonfinancial company characteristics on mandatory disclosure in developing countries: the case of Bangladesh, International Journal of Accounting Education and Research, 29(1): 62-77.

[6] Al-Akra, M., Eddie, I. A. and Ali, M. J. 2010. The influence of the introduction of accounting disclosure regulation on mandatory disclosure compliance: evidence from Jordan. The British Accounting Review, 42 (3): 170-186.

[7] Alanezi, F. S. and Albuloushi, S. S. 2011. Does the existence of voluntary audit committees really affect IFRS-required disclosure? The Kuwaiti evidence, International Journal of Disclosure and Governance, 8(2): 148-173.

[8] Alfraih, M. M. 2016. The effectiveness of board of directors' characteristics in mandatory disclosure compliance, Journal of Financial Regulation and Compliance, 24(2):154176

[9] Anderson, R., Mansi, S. and Reeb, D. 2004. Board characteristics, accounting report integrity, and the cost of debt. Journal of Accounting and Economics, 37(3): 315-342.

[10] Ball, R., Robin, A. and Wu, J. 2003. Incentives versus standards: properties of accounting income in four East Asian countries and implications for acceptance of IAS. Journal of Accounting and Economics, 36(1-3): 235-270.

[11] Barth, M. W. Landsman, and M. Lang. 2008. International Accounting Standards and accounting quality. Journal of Accounting Research, 46 (3): 467-498.

[12] Beuselinck, C., P. Joos, and S. V. D. Meulen. 2007. International earnings comparability. Working paper, Tilburg University.

[13] Bova, F. and Pereira, R. 2012. The determinants and consequences of heterogeneous IFRS compliance levels following mandatory IFRS adoption: evidence from a developing country. Journal of International Accounting Research, 11(1): 83-111.

[14] Brown, P. 2011. International financial reporting standards: what are the benefits? Accounting and Business Research, 41(3): 269-285. 
[15] Byrne, J. 2002. How to fix corporate governance. Business Week, May 6, available at: www. businessweek.com:/print/magazine/content/02_18/b3781701.h tm.

[16] Chalevas, C. G. 2011. The effect of the mandatory adoption of corporate governance mechanisms on executive compensation. The International Journal of Accounting, 46(2): 138-174.

[17] Chen, C. J. and Jaggi, B. 2000. Association between independent nonexecutive directors, family control and financial disclosures in Hong Kong. Journal of Accounting and Public Policy, 19(4-5): 285-310.

[18] Cooke, T. E. 1992. The impact of size, stock market listing and industry type on disclosure in the annual reports of Japanese listed corporations. Accounting and Business Research, 22(87): 229-237.

[19] Covrig, V. M., M. L. DeFond, and M. Hung. 2007. Home bias, foreign mutual fund holdings, and the voluntary adoption of International Accounting Standards. Journal of Accounting Research 45 (1): 1-70

[20] Cuijpers, R., and W. Buijink. 2005. Voluntary adoption of non-local GAAP in the European Union: a study of determinants and consequences. European Accounting Review 14 (3): 487-524.

[21] Daske, H., L. Hail, C. Leuz, and R. Verdi. 2008. IFRS reporting around the world: early evidence on the economic consequences. Journal of Accounting Research 46 (5): 10851142 .

[22] Deakin, S. and Konzelmann, S. 2004. Learning from Enron. Corporate Governance, 12(2): 134-142.

[23] Dumontier, P., and B. Raffournier. 1998. Why firms comply voluntarily with IAS: an empirical analysis with Swiss data. Journal of International Financial Management and Accounting 9 (3): 216-245.

[24] Felo, A., Krishnamurthy, S. and Solieri, S. 2003. Audit committee characteristics and the perceived quality of financial reporting: an empirical analysis. Working paper, Pennsylvania State University, Malvern, PA.

[25] Forker, J. 1992. Corporate governance and disclosure quality. Accounting and Business Research, 22(86): 111-124.

[26] Ghazali, N. A. M., and Weetman, P. 2006. Perpetuating traditional influences: voluntary disclosure in Malaysia following the economic crisis. Journal of International Accounting, Auditing, and Taxation, 15(2): 226-248.

[27] Haniffa, R. M. and Cooke, T. E. 2002. Culture, corporate governance, and disclosure in Malaysian corporations. Abacus, 38(3): 317-349.

[28] Ho, S. and Wong, K. 2001. A study of the relationship between corporate governance structures and the extent of voluntary disclosure. Journal of International Accounting, Auditing, and Taxation, 10(2): 139-156.

[29] Hodgdon, C., Tondkar, R. H., Adhikari, A. and Harless, D. W. 2008. Compliance with IFRS disclosure requirements and individual analysts forecast errors, Journal of International Accounting, Auditing, and Taxation, 17(1):1-13.

[30] Hodgdon, C., Tondkar, R. H., Adhikari, A. and Harless, D. W.
2009, Compliance with international financial reporting standards and auditor choice: new evidence on the importance of the statutory audit, The International Journal of Accounting, 44(1): 33-55.

[31] Hung, M., and K. R. Subramanyam. 2007. Financial statement effects of adopting International Accounting Standards: the case of Germany. Review of Accounting Studies 12 (4): 623657.

[32] Inchausti, B. 1997. The influence of company characteristics and accounting regulation on information disclosed by Spanish firms. European Accounting Review. 6(1): 45-68.

[33] Jarva, H., and A. M. Lantto. 2012. The value-relevance of IFRS versus domestic accounting standards: evidence from Finland. The Finnish Journal of Business Economics, 2: 141177.

[34] Jeanjean, T., and H. Stolowy. 2008. Do accounting standards matter? an exploratory analysis of earnings management before and after IFRS adoption. Journal of Accounting and Public Policy 27: 480-494.

[35] Jensen, M. C. and Meckling, W. H. 1976. Theory of the firm: managerial behavior, agency costs, and ownership structure. Journal of Financial Economics, 3(4): 305-360.

[36] Jensen, M. C. 1993. The modern industrial revolution, exit and the failure of internal control systems, Journal of Finance, 48(3): 831-880.

[37] John, K. and Senbet, L. 1998. Corporate governance and board effectiveness. Journal of Banking and Finance, 22(4): 371-403.

[38] Juhmani, O. 2017. Corporate governance and the level of Bahraini corporate compliance with IFRS disclosure, Journal of Applied Accounting Research, 18(1): 22 - 41.

[39] Kim, J., and H. Shi. 2014. International Financial Reporting Standards, institutional infrastructures and costs of equity capital around the world. Review of Quantitative Finance and Accounting, 42(3): 469-507

[40] Klein, A. 2002. Economic determinants of audit committee independence. The Accounting Review, 77(2): 435-452.

[41] Krismiaji, Y A. Aryani, and D. Suhardjanto. 2016. International Financial Reporting Standards, board governance, and accounting quality - A preliminary Indonesian evidence. Asian Review of Accounting, 24(4): 474 $-497$.

[42] Landsman, W. R., E. L. Maydew, and J. R. Thornock. 2012. The information content of annual earnings announcements and mandatory adoption of IFRS. Journal of Accounting \& Economics, 53(1-2): 34-54.

[43] Makhija, A. K. and Patton, J. M. 2004. The impact of firm ownership structure on voluntary disclosure: empirical evidence from Czech annual reports. The Journal of Business, 77(3): 457-491.

[44] Marston, C. and Polei, A. 2004. Corporate reporting on the internet by German companies. International Journal of Accounting Information Systems, 5(3): 285-311.

[45] Mazni, A. 2011. Compliance with international financial reporting standards (IFRS) in a developing country: the case of Malaysia. Theses, University of Stirling. 
[46] Meek, G., Roberts, C. B., and Gray, S. J. 1995. Factors influencing voluntary annual report disclosures by US, UK, and continental European multinational corporations. Journal of International Business Studies, 26(3): 555-572.

[47] Nelson, J., Gallery, G., and Percy, M. 2010. Role of corporate governance in mitigating the selective disclosure of executive stock option information, Accounting \& Finance, 50(3): 685717 .

[48] Noe, T. 2002. Investor activism and financial market structure. Review of Financial Studies, 15(1):289-318.

[49] Omar, B. 2015. The Changes of Disclosure in Compliance with the New Regulations in Jordan, International Business Research, 8 (2): 155-172

[50] Owusu-Ansah, S. 1998. The impact of corporate attributes on the extent of mandatory disclosure and reporting by listed companies in Zimbabwe. The International Journal of Accounting, 33(5): 605-631.

[51] Paananen, M. 2008. The IFRS adoption's effect on accounting quality in Sweden. Working paper, University of Hertfordshire.

[52] Paananen, $M$ and C. Lin. 2009. The Development of accounting quality of IAS and IFRS over time: The case of Germany. Journal of International Accounting Research, 8(1): $31-55$

[53] Pope, P. F. and McLeay, S. J. 2011. The European IFRS experiment: objectives, research challenges, and some early evidence. Accounting and Business Research, 41(3): 233-266.

[54] Ramsay, I. 2001. Independence of Australian company auditors: a review of current Australian requirements and proposals for reform, Commonwealth of Australia, ACT, Canberra.

[55] Sabia, M. and Goodfellow, J. 2003. Integrity in the Spotlight: Opportunities for Audit Committees. The Canadian Institute of Chartered Accountants, Toronto, December.

[56] Samaha, K., Dahawy, K., Hussainey, K. and Stapleton, P. 2012. The extent of corporate governance disclosure and its determinants in a developing market: the case of Egypt. Advances in Accounting, 28(1): 168-178.
[57] Sellami, Y. M. and H. B. Fendri. 2017. The effect of audit committee characteristics on compliance with IFRS for related party disclosures: Evidence from South Africa, Managerial Auditing Journal, 32 (6):603-626, https://doi.org/10.1108/MAJ-06-2016-1395

[58] Smith, R. 2003. Audit committees: combined code guidance report, Financial Reporting Council, London.

[59] Song, J. and Windram, B. 2004. Benchmarking audit committee effectiveness in financial reporting. International Journal of Auditing, 8(3): 195-205.

[60] Street, D., S. Gray, and S. Bryant. 1999. Acceptance and observance of International Accounting Standards: an empirical study of companies claiming to comply with IASs. International Journal of Accounting 34 (1): 11-48.

[61] Tarca, A., 2004. International convergence of accounting practices: choosing between IAS and US GAAP. Journal of International Financial Management and Accounting 15(1): 60-91.

[62] United Nations Conference on Trade and Development. 2006. Guidance on Good Practices in Corporate Governance Disclosure, United Nations Conference on Trade and Development, New York, NY.

[63] Verriest, A., Gaeremynck, A. and Thornton, D. B. 2013. The impact of corporate governance on IFRS adoption choices. European Accounting Review, 22(1): 39-77.

[64] Vicknair, D., K. Hickman, and K. C. Carnes. 1993. A note on audit committee independence: Evidence from the NYSE on" grey" area directors. Accounting Horizons, 7(1): 53-57.

[65] Wallace, R. S. O., Naser, K. and Mora, A. 1994. The relationship between the comprehensiveness of corporate annual reports and firm characteristics in Spain. Accounting and Business Research, 25(97): 41-53.

[66] Williamson, O. E. 1984. Corporate governance. Yale Law Journal, 93(7): 1197-1230.

[67] Yermack, D. 1996. Higher market valuation of companies with a small board of directors. Journal of Financial Economics, 40(2): 185-211. 